\title{
Harvestmen (Arachnida, Opiliones) from Talysh, with description of a new genus and other taxonomical changes
}

\author{
Nataly Yu. SnegovaYA* and Wojciech StaręGA* \\ *Zoological Institute NAS of Azerbaijan, proezd 1128, kvartal 504, Baku, AZE1073, Azerbaijan; e- \\ mail:snegovaya@yahoo.com \\ **Institute of Biology, Life Sciences and Humanistic University, Prusa 12, 08-110 Siedlce, Poland; \\ e-mail:wojstar@op.pl
}

\begin{abstract}
From the Talysh region in Azerbaijan 14 species of harvestmen were recorded during the field investigations of the senior author. One genus and species were new for science and one new for the region. Two names have to be synonymized and one species transferred to other genus.
\end{abstract}

Key words: Opiliones, Talysh, Azerbaijan, Lenkoraniella nigricoxa, new species, new genus, new synonymy

\section{INTRODUCTION}

The mountainous region Talysh is the south-eastern part of Azerbaijan between $38^{\circ} 24^{\prime}$ and $39^{\circ} 22^{\prime} \mathrm{N}$ and $47^{\circ} 58^{\prime}$ and $48^{\circ} 52^{\prime} \mathrm{E}$, with total area $5370 \mathrm{~km}^{2}$. It adjoins on the North with Mugan Steppe, on the East - with Caspian Sea and on the South and West it forms the border with Iran.

Before our researches started only 12 harvestmen species were known from Talysh. The data of Morin (1937) repeated by Bogachev (1951): Acropsopilio talischensis Morin, Opilio coxipunctus (Sørensen), O. ejuncidus Thorell, O. lepidus L. Koch, O. consputus (Simon), O. pallens (Kulczyński), Zacheus bispinifrons Roewer, being either doubtful or simply incredible and the revision of the Morin's material is impossible - there is nothing left (either destroyed before or during the War). Reliable were only the data of other authors (Roewer 1919, 1923, 1951, Starega 1978, Martens 2006): Paranemastoma filipes (Roewer), Mediostoma variabile Martens, M. nigrum Martens, Phalangium punctipes L. Koch, "Rilaena pusilla (Roewer)".

As a result of our systematical research in Talysh (Snegovaya 1999, 2004, 2005, 2007; Snegovaya \& Starega 2008, recent paper) one genus and 7 species (Lenkoraniella nigricoxa gen. and sp. n., Phalangium armatum Snegovaya, 2005, Ph. zuvandicum Snegovaya, 2005, Ph. staregai Snegovaya, 2005, Rilaena azerbaijanica Snegovaya, 2007, Metaplatybunus talyshicus Snegovaya, 2007, and Homolophus azerbaijanicus Snegovaya et Staręga, 2008) were described as new for science, three species as new for Azerbaijan (Zachaeus birulai Redikorzev, 1936, Dicranolasma ponticum Gruber, 1998, Opilio hemseni Roewer, 1952), and two species as new for this territory [Opilio parietinus (De Geer, 1778), O. lederi Roewer, 1911]. Two names are going herein in synonymy (Phalangium zuvandicum Snegovaya, 2005 and Homolophus azerbaijanicus Snegovaya et Starega, 2008) and one species is transferred to another genus (Metaplatybunus talyshicus Snegovaya, 2007 to Rilaena Silh.).

Names of collectors are abbreviated as follows: Drs Elchin Guseinov (E.G.), Denis Kasatkin (D.K.), Yuri Marusik (Yu.M.) and the senior author (N.S.). Other abbreviations used in the text are: IZB (+ a catalogue number) - Zoological Institute of the National Academy of 
Sciences of Azerbaijan, Baku, ZIN - Zoological Institute of the Russian Academy of Sciences, Sankt Petersburg and RCNS - reference collection of Nataly Snegovaya.

\title{
LIST OF SPECIES
}

Trogulidae

\section{Platybessobius caucasicus Šilhavý, 1966}

Material: 1 juv., Lenkoran, Apo, 17.06.2007 (IZB 336).

Records: Lenkoran (Snegovaya 1999, 2004).

Dicranolasmatidae

\section{Dicranolasma ponticum Gruber, 1998}

\author{
(Figs 1-6)
}

Dicranolasma giljarovi: Snegovaya 2004: 308, (part.), nec Šilhavý, 1966

Material: 1 कै, Lenkoran, Apo, 17.06 .2007 (IZB 328), D.K., N.S.; 1 \&, 1 , Azfilial, 17.05.2007 (IZB 328), N.S.; 1 ô, Lerik, 28.05.2005, N.S.

Records: Lenkoran (Snegovaya 2004).

Nemastomatidae

\section{Mediostoma variabile Martens, 2006}

Mediostoma sp.: Snegovaya 2004: 308-309, ff. 9-13, map 2

Material: Lenkoran, Girkan State Reserve, near Khanbulanchay water reservoir,

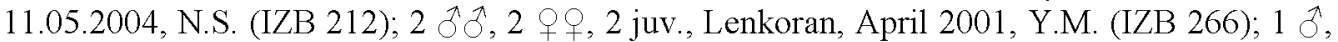

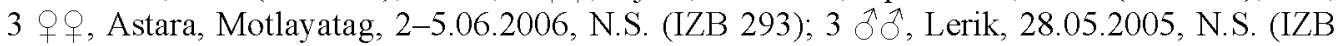
301); 1 q, 1 juv., Lenkoran, Azfilial, 17.05.2007, N.S. (IZB 321); 1 ㅇ, 2 juv., Lenkoran, Apo, litter, 18.05.2007 (IZB 322); $3 \widehat{\partial}, 3$ q9, Lerik, environs of Peshtatyuk village, 14-6.06.2007,

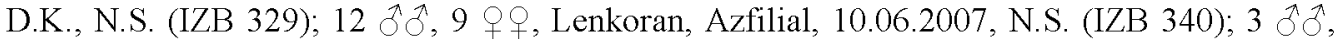
6 우, Lenkoran, Apo, 17.06.2007, N.S. (IZB 343); 5 qq, Yardimli, near Kyurekchi village, ca. $1700 \mathrm{~m}$ a.s.1., 26.05.2008, N.S. (IZB 367); 1 o, 1 o, 4 juv., same locality and time, N.S. (IZB 373); 1 q, 3 juv., same locality, 30.05.2008, N.S. (IZB 374); $2 \hat{\partial} \hat{\jmath}, 7$ qq, Lenkoran, Azfilial, 24.05.2010, N.S. (RCNS).

Records: Lenkoran (Snegovaya 2004, Martens 2006)

\section{Paranemastoma filipes (Roewer, 1919)}

Material: 1 $\hat{\jmath}, 4$ 우, Lenkoran, April 2001 (IZB 264), Y.M.; $2 \hat{\jmath}, 10$ 우, Azfilial, 30.05-2.06.2006, N.S. (IZB 288); $27 \hat{\jmath}, 14 \phi 9$, same place and data, N.S. (IZB 289); $12 \hat{\partial \delta}, 5$ 우, same place and data, N.S., (IZB 290); $3 \hat{\jmath} \hat{\partial}, 3$ qq, Astara, Motlayatag, 25.06.2006, N.S. (IZB 294); $10 \delta \hat{\partial}, 9$ q9, Azfilial, 10-18.07.2005, E.G. (IZB 298); $1 \hat{\partial}, 1$ †, 1 juv., Lenkoran, 2003, E.G. (IZB 303); 30 juv., Azfilial, 14-16.11.2006, E.G. (IZB 319); $3 \partial \hat{\partial}, 7$ q, Azfilial, 17.05.2007, N.S. (IZB 326); 1 o, 2 qq, Azfilial, 10.06.2007, N.S. (IZB 331); 3 ठิ, 4 ㅇ․, Azfilial, 18.06.2007, N.S. (IZB 352); 1 है, Girkan State Reserve, 56.06.2008, D.K. (IZB 387); $6 \hat{\delta}, 3$ qq, Lenkoran, Azfilial, 24.05.2010, N.S. (RCNS).

Records: Lenkoran (Roewer 1919, 1951, Martens 2006). 


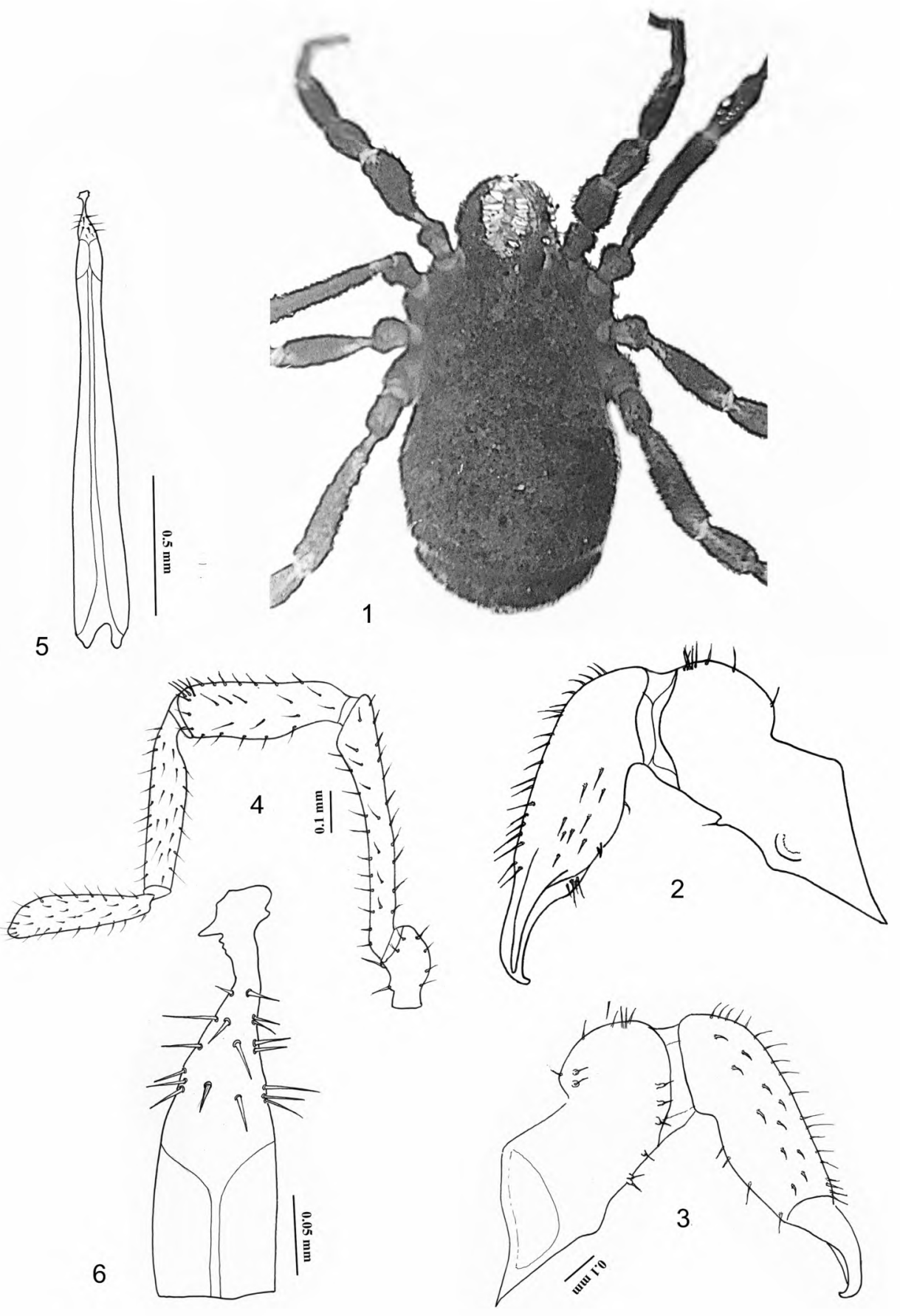

Figs 1-6. Dicranolasma ponticum Gruber, 1998: 1 - dorsal view of male; right chelicera: 2 - prolateral and 3 retrolateral view; 4 - right pedipalpus, prolateral view; 5 - penis dorsal view 6 - glans dorsal view. 
Phalangiidae

\title{
Phalangium punctipes L. Koch, 1878
}

Material: 2 qq, Lenkoran, Moscow forest, 21.05.2007, N.S. (IZB 327); 1 \%, Yardimli, near Kyurekchi village, ca. $1700 \mathrm{~m}$ a.s.1., 25.05.2008, D.K., N.S. (IZB 359); $1 \hat{\delta}, 1$ q, same locality and time, N.S. (IZB 380); 2 90, same locality, 27.05.2008, N.S. (IZB 361); $4 \delta \delta$, 3 qq, same locality, 26.05.2008, N.S. (IZB 365); 1 of, same locality and time, N.S. (IZB 381); 4 우, same locality, 30.05.2008, N.S. (IZB 378); 1 ठै, Yardimli, environs of Uzyubashi Mt., ca. 2000-2200 m a.s.1., 29.05.2008, N.S. (IZB 368).

Records: Lenkoran (Bogachev 1951); systematics cleared up by Staręga (1966)

\section{Phalangium armatum Snegovaya, 2005}

\author{
Phalangium savignyi: Snegovaya 1999: 455, ff. 9-13; 2004: 313, ff. 17-19, nec Audouin, 1825 \\ Phalangitum armatum Snegovaya, 2005: 22-26, ff. 17-34 \\ Phalangium zuvandicum Snegovaya, 2005: 23-28, ff. 35-45, syn. n.
}

Material: 1 dै, Lerik, Gosmalyan, 28.05.2005, N.S. (IZB 297); 1 q, Lerik, May 2003, E.G. (IZB 302); 4 우, Lerik, Gosmalyan, 12.06.2007, N.S. (IZB 337); $1 \hat{\jmath}$, same place, 11.06.2007, N.S. (IZB 339); 3 9q, same place, 12.06.2007, N.S. (IZB 347); 3 q , Lerik, near Devil"s bridge, 14.06.2007, D.K., N.S. (IZB 350); 1 dै, Yardimli, near Kyurekchi village, ca. $1700 \mathrm{~m}$ a.s.1., 25.05.2008, N.S. (IZB 357); $4 \hat{\partial} \vec{\delta}, 1$ q, same locality, 26.05.2008, D.K., N.S. (IZB 360); $5 \hat{\delta}, 1$, same locality and time, D.K., N.S. (IZB 362); $2 \hat{\delta}, 1$, same locality, 26-27.05.2008, D.K., N.S. (IZB 376); 1 o, 1 ㅇ, Yardimli, environs of Uzyubashi Mt., ca. 2000

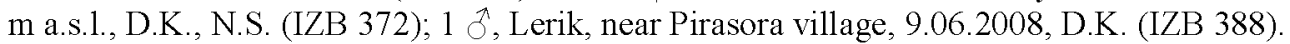

Phalangium zuvandicum has been described on specimens with not fully developed characters (cheliceral "horns", body and eye mound armature) but penis structure has shown that they are identical with $P h$. armatum. Therefore both names must be regarded as synonyms. We use the name Phalangium armatum because it has page priority and has been founded on specimens with better visible typical characters. This is a common phenomenon within the subfamily Phalangiinae, in genera with wide sex dimorphismus [e.g. Zachaeus C.L.K. (Šilhavý 1965), Phalangium L. (Martens 1978) or Rhampsinitus Sim. (Staręga 2009)].

Records: Lerik (Snegovaya 1999, 2004, 2005).

\section{Phalangium staregai Snegovaya, 2005}

Material: 1 d, 3 qq, Lerik, Gosmalyan, 12.06.2007, N.S. (IZB 330); 1 đ, 7 qq, same place, 11.06.2007, N.S. (IZB 331); 3 $\hat{\delta}, 3$ q, , Yardimli, environs of Uzyubashi Mt., ca. 2000-2200 m a.s.1., 29.05.2008, D.K., N.S. (IZB 382); 5 qq, Lerik, environs of Pirasora village, 7-9.06.2008, D.K. (IZB 389).

Records: Lerik (Snegovaya 2005).

Rilaena talyshica (Snegovaya, 2007), comb. n.

(Figs 7-11)

Metaplatybunus talyshicus Snegovaya, 2007: 88-90, ff. 1-9

Material: $1 \delta$, Lenkoran, Azfilial, 30.05.-2.06.2006, N.S. (IZB 295); $1 \hat{\delta}$, Yardimli, near Kyurekchi village, ca. $1700 \mathrm{~m}$ a.s.1., 30.05.2008, N.S. (IZB 379); $4 \hat{\jmath} \hat{\jmath}, 11$ 우, 3 juv., same place, 27.05.2008, N.S. (IZB 384); 3 ㅇ, 2 juv., same place and time, D.K. (IZB 390); $1 \hat{\jmath}$, 
2 우, $25 \mathrm{~km}$ from Yardimly, 1-3.06.2008, D.K. (IZB 383); $9 \hat{\jmath}, 1 q$ (RCNS), Lenkoran, Azfilial, 19-21.05.2009, N.S.

Records: Lenkoran, Yardimli (Snegovaya 2007).

The penis structure (Snegovaya 2007, ff. 6-9) shows that this species should be transferred to Rilaena Šilh. - it is typical for the subfamily Phalangiinae.

Female differs from male by bigger and more rounded body. Measurements: body length 5.9 , width 3.1 ; basal segment of chelicera 1.25 , distal one 1.65 ; length of palpal segments femur 1.39 , patella 0.9 , tibia 1.0 , tarsus 1.6 , total length $4.89 \mathrm{~mm}$; length of legs: I $4.25+1.0+3.0+5.0+5.55=18.8$, II $8.0+1.2+6.55+9.5+12.25=37.5$, III $4.5+1.2+3.25+6.0+6.2=$ 21.15 , IV $7.0+1.2+3.1+5.75+6.2=23.25$; ovipositor length 2.8 .
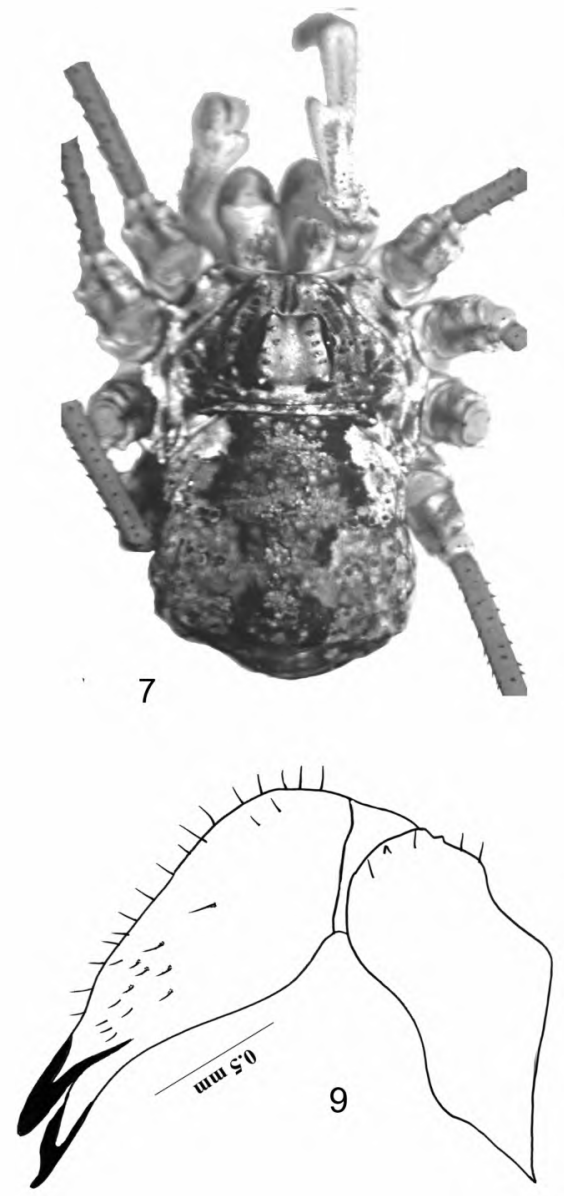
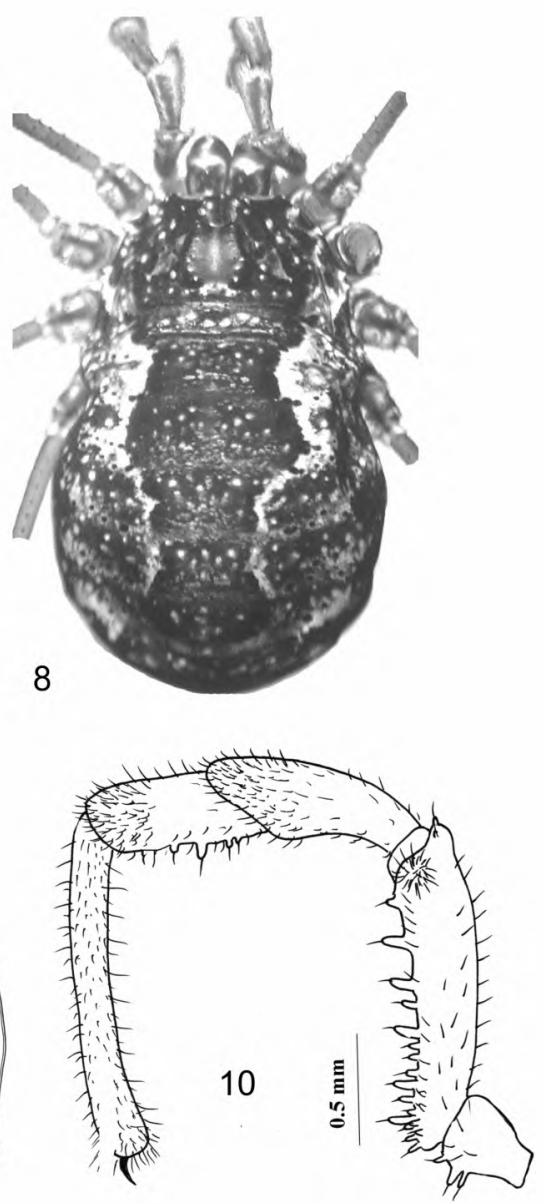

Figs 7-11. Rilaena talyshica (Snegovaya, 2007), comb. n.: dorsal view of body: 7 - male, 8 - female; 9 - prolateral view of right female chelicera; 10 -prolateral view of right female pedipalpus; 11 - seminal receptacle. 


\section{Rilaena lenkoranica Snegovaya, 2007}

(Figs 12-16)

Rilaena pusilla: Staręga 1978: 218, Snegovaya 1999: 455, ff. 29-33; 2004: 318, ff. 36-41, nec Roewer, 1952

Material: $2 \hat{\partial}$, Lenkoran, Azfilial, 14.05.2007, N.S. (IZB 323); $1 \hat{\partial}$, same place, 10.06.2007, N.S. (IZB 345); $1 \hat{\partial}$, Apo, 17.06.2007, N.S. (IZB 354); $1 \hat{\partial}$, Azfilial, 30.052.06.2006, N.S. (IZB 355); 3 $\partial, 1$, Lenkoran, Azfilial, 19-21.05.2009, N.S. (RCNS); $25 \hat{\delta}, 2$ 오, Lenkoran, Azfilial, 24.05.2010, N.S. (RCNS).

Records: Lenkoran (Staręga 1978, Snegovaya 1999, 2004, 2007).

Female differs from male by bigger body and lighter coloration.

Measurements: body length 8.0 , width 3.1 ; chelicera: basal segment 2.0 ; distal segment 2.2;

length of palpal segments: femur 1.7, patella 1.2, tibia 1.1, tarsus 2.1 ; total length $6.1 \mathrm{~mm}$; length of legs: I $4.0+1.5+3.3+5.3+7.0=21.1$, II $8.2+1.6+6.5+8.5+14.5=39.3$, III $5.0+1.5+3.5+6.3+8.0=24.3$, IV $8.0+2.0+5.0+10.5+9.0=34.5$; ovipositor length 4.5 .

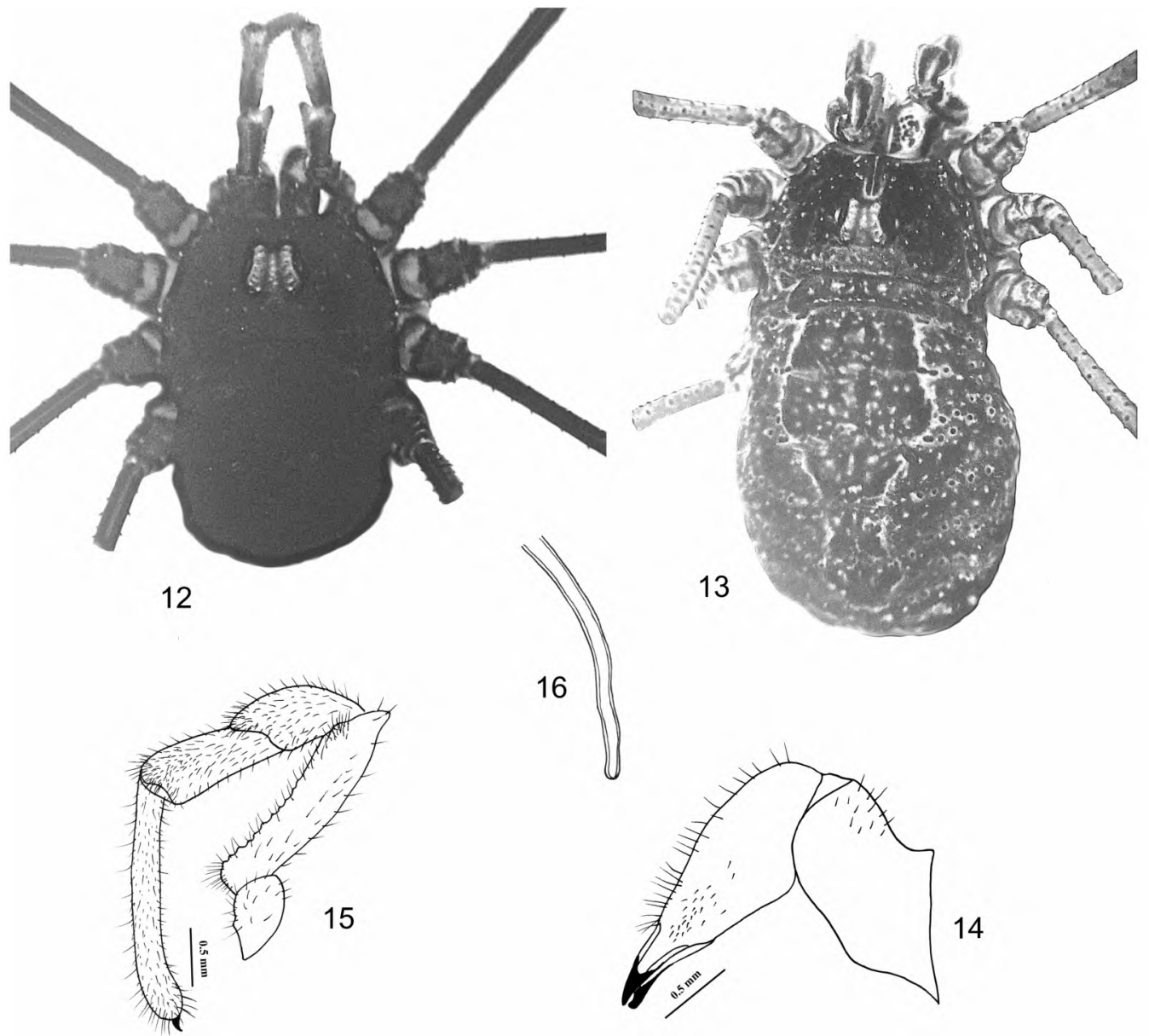

Figs 12-16. Rilaena lenkoranica Snegovaya, 2007: dorsal view of body: 12 - male, 13 - female; 14 - prolateral view of right female chelicera; 15 - prolateral view of right female pedipalpus; 16 - seminal receptacle. 


\section{Zachaeus birulai Redikorzev, 1936}

Zacheus crista (Brulle, 1832): Snegovaya 1999: 458, ff. 40-44; 2004: 313, ff. 20-25

Material: $3 \hat{\jmath} \hat{\jmath}, 4$ q 9 , Lenkoran, Azfilial, 30.05.-7.06.2006, N.S. (IZB 292); 1 q, Lerik, Gosmalyan, 11.06.2007, N.S. (IZB 353); 1 ઈ, 1 †, Lenkoran, Azfilial, 24.05.2010, N.S. (RCNS).

Records: Lenkoran (Snegovaya 1999, 2004).

\section{Opilio parietinus (De Geer, 1778)}

Material: $2 \hat{\partial}, 2$ q+, 4 juv., Astara, Motlayatag, 2.-5.06.2006, N.S. (IZB 291); 1

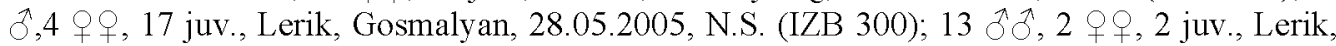
$10 \mathrm{~km}$ from the town, 6.09.2004, N.S. (IZB 314); 2 우, 8 juv., Lerik, Gosmalyan, 12.06.2007, N.S. (IZB 333); $2 \hat{\jmath}, 1$ juv., same place, 11.06.2007, N.S. (IZB 334); 1 ô, Lerik, Peshtatyuk, 14-16.06.2007, N.S. (IZB 342); 1 †, 2 juv., Lerik, Gosmalyan, 11.06.2007, D.K., N.S. (IZB 344); $8 \hat{\jmath}, 4$ of , same place, 12.06.2007, D.K., N.S. (IZB 346).

Records: Lenkoran (Snegovaya 1999, 2004).

\section{Opilio lederi Roewer, 1911}

Material: 1 q, Yardimli, near Kyurekchi, ca. 1700 m a.s.1., 25.05.2008, N.S. (IZB 358); $1 \AA$, Yardimli, environs of Uzyubashi Mt., ca. $2000 \mathrm{~m}$ a.s.1., D.K. (IZB 371).

Records: First records in Talysh, previously known from several localities in Georgia, Armenia, Azerbaijan, North Ossetia and North Iran (Roewer 1911, 1923, Starega 1978, 2003, Snegovaya 1999, 2004).

\section{Opilio hemseni Roewer, 1952}

(Figs 17-20)

Homolophus azerbaijanicus Snegovaya et Staręga, 2008: 15-17, ff. 1-11, syn. n.

Material. 2 fo, 1 9, 1 juv., Lenkoran, Hirkan, Apo, 17.06.2007, D.K., N.S. (IZB 341); 1 \&, 10 juv., Lerik, environs of Peshtatyuk, 14-16.06.2007, D.K., N.S. (IZB 348); 6 ठ̊., 8 ㅇ, 2 juv., Azfilial, 18.06.2007, D.K., N.S. (IZB 349); 2 q9, 11 juv., 25 km from Yardimly, 1-3.06.2008, D.K. (IZB 385); $6 \hat{\delta} \hat{d}, 2$ 우, 1 juv., Lenkoran, environs of Byurdjali (old name Alekseevka), 7-9.06.2008, D.K. (IZB 386).

Records: Lenkoran (Snegovaya \& Starega 2008). Described from Iran (Roewer 1952).

Homolophus azerbaijanicus has been described on relative darker specimens (anyway with very dark saddle). Our material has been now compared with the holotype of Opilio hemseni (SMF R II/10721/322). It is lighter and has dark spots on all coxae - typical for the genus Opilio Herbst; the penes in all series are identical. There is a question if the species should belong to Opilio Herbst, where it fits better according to habitus and zoogeography or to Homolophus Banks, which has indeed similar glans shape but does not fit geographically - the distribution center of the genus lying in Central and East Asia.

So, we synonymize both names but leave the species provisionally in the genus Opilio.

Female differs from male by more rounded body and lacking of any armature on chelicera.

Measurements: body length 4.5, width 2.4; basal segment of chelicerae 1.25, distal 1.48; length of palpal segments: femur 1.13 , patella 0.5 , tibia 0.65 , tarsus 1.53 , total length 3.81 ; length of legs: I $4.6+1.2+3.7+4.7+8.6=22.8$, II $10.0+1.5+8.5+5.6+22.0=47.6$, III $5.0+1.2+4.1+5.0+8.7=24.0$, IV $6.5+1.5+6.2+7.5+13.0=34.7$; ovipositor length 1.75 . 

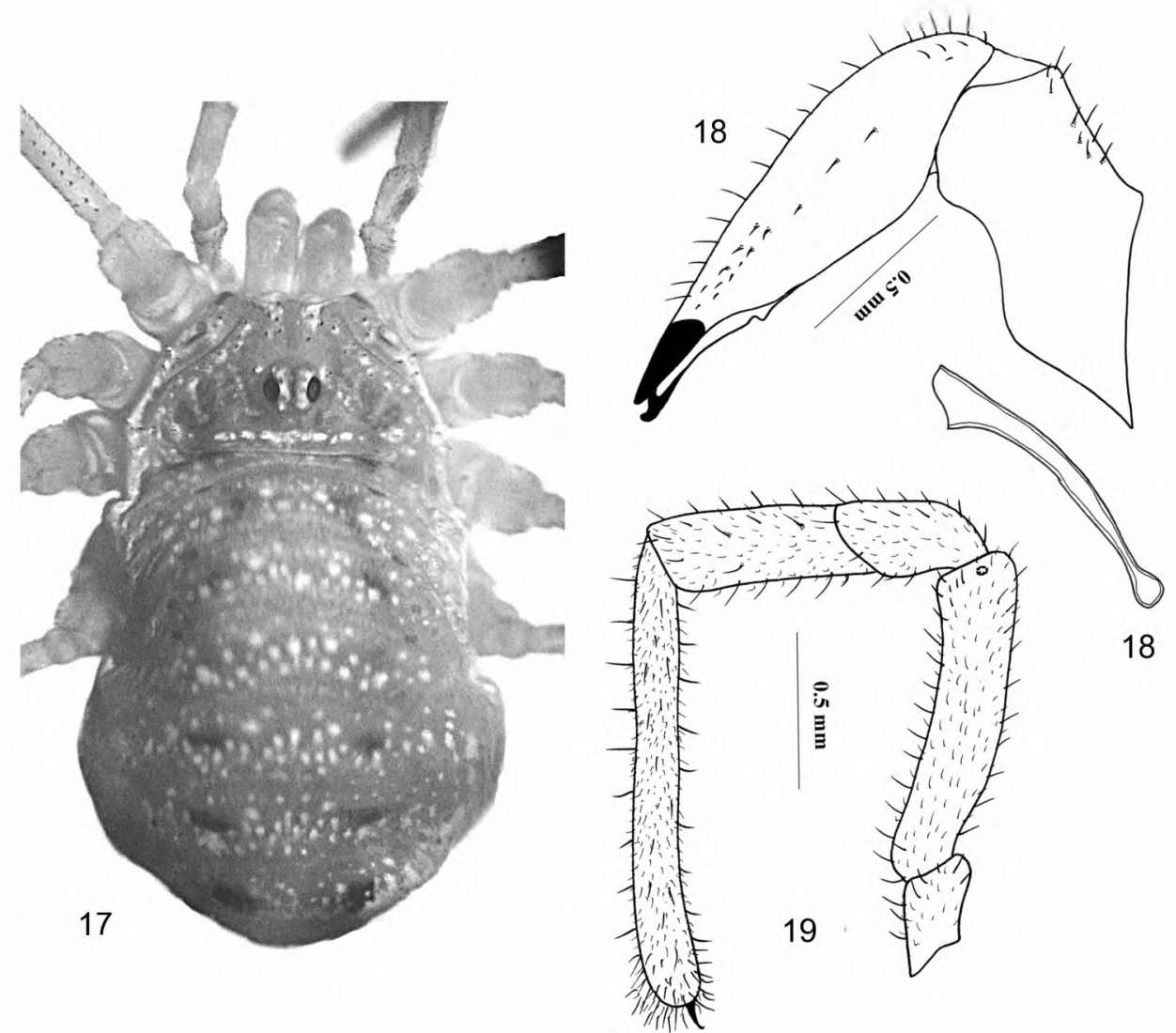

Figs 17-20. Opilio hemseni Roewer, 1952: 17 - dorsal view of female body; 18 - prolateral view of right female chelicera; 19 - prolateral view of right female pedipalpus; 20 - seminal receptacle.

\section{Lenkoraniella gen. $\mathbf{n}$.}

Diagnosis. Small-sized harvestman with soft, smooth body, only with a group of hardly visible denticles in front of eye mound. Eye mound small, round, with very small and thin setae. Chelicera small, basal segment with a unusual horizontal row of large denticles laterally and with some small denticles dorsally. Pedipalps short, without apophyses, covered only with setae. Legs short, with hairs, femora I ventrally with rows of small hair-tipped denticles. Penis short, shaft with characteristic subapical "spoon" dorsally, glans long, expanded in midpart, stylus long.

Most similar to Rilaena, but differs from it by:

- smaller and rounded eye mound;

- lacking apophyses on pedipalps;

- having denticles laterally and dorsally on basal segment of chelicerae;

- having expanded midpart glans.

Species typica (monotyp.): Lenkoraniella nigricoxa sp. n. 
The most characteristic (but not diagnostic) character is a coloration of legs: alternating dark and light rings of nearly the same width. It is good visible on living specimens in the field and unique among the whole subfamily Phalangiinae.

Etymology. The genus is named after its type locality Lenkoran; the gender of the name is feminine.

Distribution: Azerbaijan.

\section{Lenkoraniella nigricoxa sp. $n$.}

(Figs 21-34)

Material: $1 \hat{\delta}$ (holotype), $2 q q$ (paratypes) (ZIN). Paratypes: $2 \hat{\jmath}, 24 q q$, (RCNS), Lenkoran, Azfilial, 19-21.05.2009, leg. N. Snegovaya; 2 q (IZB N356), Yardimli, environs of Kyurekchi, ca. $1700 \mathrm{~m}$ a.s.1., 25.05.2008, leg. N. Snegovaya, D. Kasatkin; 1 Q (IZB N363), the same place, 26.05.2008, leg. D. Kasatkin; 4 99 (IZB N364), the same place and date; 8 qq (IZB N369), environs of Uzyubashi Mt., ca. 2000-2500 m, 29.05.2008, leg. N. Snegovaya, D. Kasatkin; 1 (IZB N370), same place and data; 2 qq (IZB N375), environs of Kyurekchi, ca. $1700 \mathrm{~m}$ a.s.1., 26.05.2008, leg. N. Snegovaya; Yardimli, 5 qq (IZN N377), the same place, 26-27.05.2008, leg. N. Snegovaya; 1 oे, 2 qq (RCWS), 1 oे, 29 q , (RCNS), Lenkoran, Azfilial, 24.05.2010, leg. N.Snegovaya

Description: Male. Small harvestman, coloration dirty-grey to dark brown with clearly visible darker saddle. Eye mound small, rounded-shape, covered with very small setae (almost invisible). In front of eye mound a group of small denticles, same denticles in front angles of carapace. Lamellae with single denticles (on each side). Abdominal segments with very short setae. Venter light brown, covered with setae, genital operculum with dark brown spots; coxae dark brown, nearly black. Body length 3.2, width 1.9 (Figs 21-22).

Chelicera small (Figs 23-24), brown with darker pattern and spots. Basal segment ventrally with large and small denticles, dorsally with denticles and setae. Basal segment of chelicera 1.1, distal 1.3.

Pedipalp short (Fig. 25). Femur ventrally with small denticles, other segments with setae, more dense prolaterally on patella and tibia. Tarsus ventrally with microdenticles. Femur brown with lighter distal and basal end, patella and tibia brown with lighter distal end, tarsus light brown with dark (almost black) distal part. Length of palpal segments: femur 0.75 , patella 0.45 , tibia 0.5 , tarsus 0.9 ; total length 2.6 .

Legs short, all segments covered with setae, only femur I ventrally with rows of small hairtipped denticles. Legs light brown clearly ringed with dark brown. Length of legs: I $1.5+0.6+1.3+1.6+2.3=7.3$, II $2.1+0.8+2.1+2.1+4.2=11.3$, III $1.3+0.6+1.3+1.9+2.3=7.4$, IV $2.0+2.8+1.7+2.7+2.8=12.0$.

Penis (Figs 26-28) length 1.55, glans 0.28, stylus 0.1. Penis wide at the basis, narrowed in the middle of shaft and then extended again, shaft with characteristic subapical "spoon" dorsally. Glans with 2 pairs of setae.

Female differs from male by larger size, absence of denticles on femora I, presence of small apophyses on pedipalp (patella and tibia), absence of denticles on basal segment of chelicerae (Figs 29-33). Body length 4.5, width 2.3. Basal segment of chelicerae 0.9, distal 1.15. Length of palpal segments: femur 0.75 , patella 0.35 , tibia 0.45 , tarsus 0.95 ; total length 2.5 . Length of legs: I $1.4+0.6+1.3+1.6+2.3=7.2$, II $2.5+1.4+2.1+2.4+4.75=13.15$, III $1.4+0.7+1.3+2.0+2.4$ $=7.8$, IV $2.1+0.8+1.8+2.9+3.3=10.9$. Ovipositor length 1.5 .

Etymology. The species is named after its very characteristc nearly black coxae. 


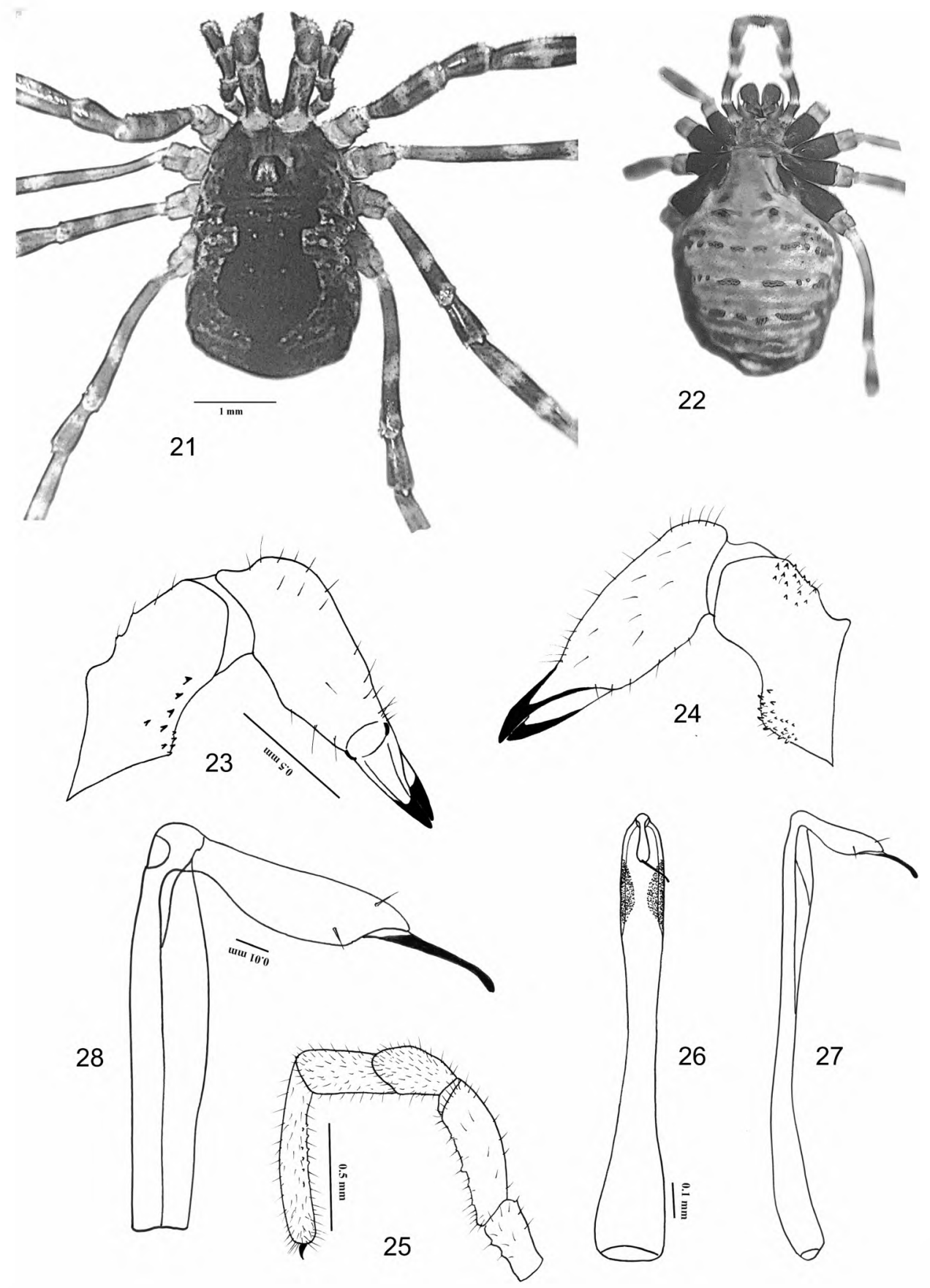

Figs 21-28. Lenkoraniella nigricoxa gen. et sp. n., male (paratype): 21 - dorsal and 22 - ventral view of body; 23 prolateral and 24 - retrolateral view of right chelicera; 25 - prolateral view of right pedipalpus; 26 - dorsal and 27 lateral view of penis; 28 - glans, lateral view. 


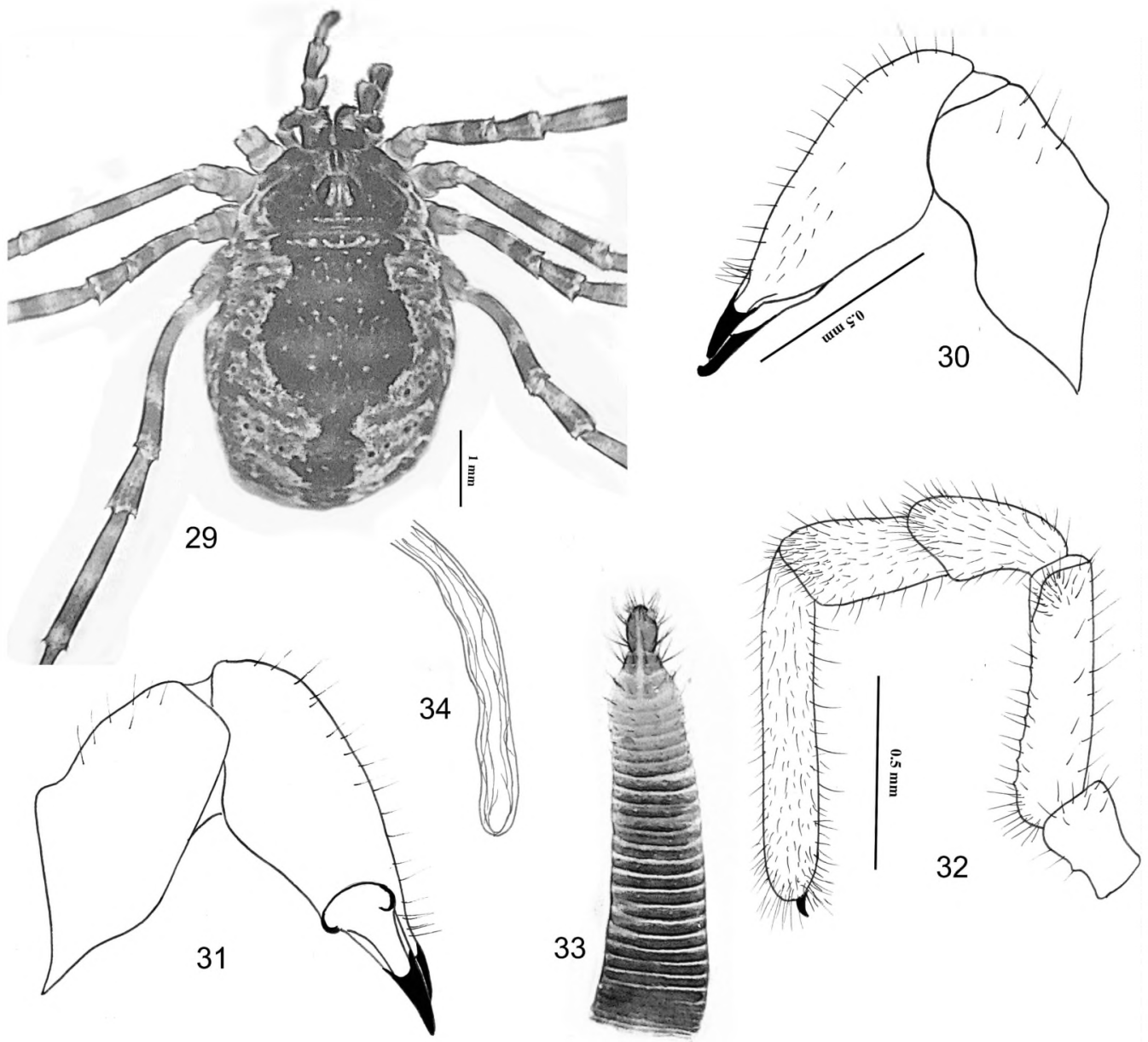

Figs 29-34. Lenkoraniella nigricoxa gen. et sp. n., female (paratype): 29 - dorsal view of body; 30 - prolateral and 31 - retrolateral view of right chelicera; 32 - prolateral view of right pedipalpus; 33 - ovipositor, 34 - seminal receptacle.

\section{ACKNOWLEDGMENTS}

We express our gratitude to Drs. E. Guseinov, Kh. Aliyev (both Baku, Azerbaijan), D. Kasatkin (Rostov-na-Donu, Russia), Yu. Marusik (Magadan, Russia) for help with collecting Opiliones. Special thanks are due to Dr. Peter Jäger (Frankfurt am Main, Germany), who kindly lent type material for studying.

\section{REFERENCES}

BogacheV A. A. 1951. Otryad senokosey - Phalangida ili Opiliones [Order Opiliones]. In: ALIZADE A. N., ASADOV S. \& M. DERZHAVIN A. N. (eds), Zhivotnyi Mir Azerbaidshana [Animal World of Azerbaidzhan], pp. 405-406. AN AzSSR, Institute of Zoology, Baku, $601 \mathrm{pp}$.

Martens J. 1978. Spinnentiere, Arachnida. Weberknechte, Opiliones. In: SENGlaub K., HaNNEManN H.-J. \& SChumann H. (eds), Die Tierwelt Deutschlands.64. G. Fischer Verl., Jena, 464 pp.

MARTENS J. 2006. Weberknechte aus dem Kaukasus (Arachnida, Opiliones, Nemastomatidae). Senckenbergiana Biologica 86: 145-210. 
Morn S. M. 1937. Kavkaz'ki Opiliones - kosari. Trudi Odes'kogo Derzhavnogo Universitetu, Biol. 2: $209-222$.

ROEwER C. F. 1911. Übersicht der Genera der Subfamilie der Phalangiini der Opiliones Palpatores, nebst Beschreibung einiger neuer Gattungen und Arten. Archiv für Naturgeschichte 77, I, 2 Suppl., 106 pp.

ROEWER C. F. 1919. Über Nemastomatiden und ihre Verbreitung. Archiv für Naturgeschichte, 83, 3 [1917]: 140-160.

ROEWER C. F. 1923. Die Weberknechte der Erde. Systematische Bearbeitung der bisher bekannten Opiliones. G. Fischer Verl., Jena, $1116 \mathrm{pp}$.

ROEWER C. F. 1951. Über Nemastomatiden. Weitere Weberknechte XVI. Senckenbergiana 32: 95-153.

ROEWER C. F. 1952. Die Solifugen und Opilioniden der Österreichischen Iran-Expedition 1949-1950. Sitzungsberichte der Österreichischen Akademie der Wissenschaften, Abteilung I, 161: 509-516.

ŠLHAVÝ V. 1965. Die Weberknechte der Unterordnung Eupnoi aus Bulgarie; zugleich eine Revision europäischer Gattungen der Unterfamilien Oligolophinae und Phalangiinae) (Arachnoidea, Opilionidea). Acta Entomologica Bohemoslovaca 62: 369-406.

SNEGOVAYA N. 1999. Contribution to the Harvest spider (Arachnida, Opiliones) fauna of the Caucasus. Turkish Journal of Zoology 23: 453-459.

SNEGovaya N. Yu. 2004. Preliminary notes on the harvestman fauna (Opiliones) of Azerbaijan. In: LOGUNOV D.V. \& PENNEY D. (eds), European Arachnology 2003. Arthropoda Selecta, Special Issue No. 1: 307-318.

SNEGOVAYA N. Yu. 2005. Four new harvestman species from Azerbaijan (Arachnida, Opiliones, Phalangiidae). Arthropoda Selecta 14: 19-32.

SNEGovayA N. Yu. 2007. Two new harvestman species from Lenkoran, Azerbaijan (Arachnida: Opiliones: Phalangiidae). Bulletin of the British Arachnological Society 14: 88-92.

Snegovaya N. Yu., Starfiga W. 2008. A new Homolophus species (Arachnida: Opiliones: Phalangiidae) from Lenkoran zone (Azerbaijan). Acta Arachnologica 57: 15-17.

STARĘGA W. 1966. Beitrag zur Kenntnis der Weberknecht-Fauna (Opiliones) der Kaukasusländer. Annales Zoologici 23: $387-411$.

STAREGA W. 1978. Katalog der Weberknechte (Opiliones) der Sowjet-Union. Fragmenta Faunistica 23: $197-241$.

STARĘGA W. 2003. On the identity and synonymies of some Asiatic Opilioninae (Opiliones: Phalangiidae). Acta Arachnologica 52: 91-102.

STAREGA W. 2009. Some southern African species of the genus Rhampsinitus Simon (Opiliones: Phalangiidae). Zootaxa 1981: 43-56.

\section{STRESZCZENIE}

\section{[Kosarze (Arachnida, Opiliones) z Talyszu, z opisem nowego rodzaju $i$ innymi zmianami taksonomicznymi]}

14 gatunków kosarzy stwierdzono w górskim obszarze Tałyszu w Azerbejdżanie. 7 z nich to gatunki nowe (w tym jeden rodzaj, z czego 6 opisano we wcześniejszych pracach), 1 nowy dla regionu. Dwie nazwy zostały uznane za synonimy innych, a jeden gatunek zostal przeniesiony do innego rodzaju. 